\title{
Evaluation of immune status against hepatitis B in children with thalassemia major in Egypt: A single center study
}

\author{
Hanan H. Soliman' ${ }^{1}$ Ibrahim A. Kabbash², Mohamed R. El-Shanshory ${ }^{3}$, Hala M. Nagy', Said H. Abdou ${ }^{4}$ \\ ${ }^{1}$ Department of Tropical Medicine and Infectious Diseases, Faculty of Medicine, Tanta University Hospital, Egypt \\ ${ }^{2}$ Department of Public Health, Faculty of Medicine, Tanta University, Egypt \\ ${ }^{3}$ Department of pediatrics, Faculty of Medicine, Tanta University Hospital, Egypt \\ ${ }^{4}$ Department of Clinical pathology, Faculty of Medicine, Tanta University Hospital, Egypt
}

\begin{abstract}
Objectives: Thalassemic children with repeated blood transfusion are at higher risk of suffering transfusion related infections including hepatitis B virus (HBV). HBV vaccine immunogenicity in several studies showed variable response rates. The aim of this study is to evaluate the immunogenic effect of hepatitis $B$ vaccine in thalassemic children at different age groups.

Materials and methods: After ethical approval and informed parent consent, 125 diagnosed thalassemic patients were recruited from the Hematology/Oncology Unit, Pediatric Department, Tanta University Hospital. Patient's transfusion, and vaccination history, clinical data, and blood samples were obtained. Patient's sera were stored at $-20^{\circ} \mathrm{C}$ till tested for Anti-hepatitis B surface (anti-HBs) by ELISA. Patients with titers <10 IU were tested for HBs-Ag.

Results: Although none of our cases had hepatitis B virus infection, only $20.8 \%$ had a protective anti-HBs titer ( $>10$ IU/L). Significantly higher percentage of protected patients (40.1\%) were younger than 3 years of age, while age groups above 3years showed a significant trend towards having non protective titers $(p=0.003)$. Anti-HBs titers weren't correlated to age, ferritin, liver enzymes, and duration of transfusion or number of transfused packs.
\end{abstract}

Conclusion: Protective Anti-HBs titer was reduced after age of 3 years in our patients. So, we recommend screening of thalassemic patients at age of 3 years to evaluate the need of a booster dose. J Microbiol Infect Dis 2012; 2(2): 44-49

Key words: Thalassemia, HBV, vaccination, immunogenicity

\section{Mısır'da talassemi major hastası çocuklarda hepatit B'ye karşı gelişen immünitenin araştırılması: Tek merkezli bir çalışma}

\section{ÖZET}

Amaç: Talassemili çocuklar tekrarlayan kan transfüzyonlarından dolayı Hepatit B virusu (HBV) dahil transfüzyonla ilişkili enfeksiyonlara daha fazla maruz kalırlar. Bu çalışmanın amacı değiş̧ik yaş gruplarındaki talassemili çocuklarda hepatit B aşısının immünojenik etkisinin araştırılmasıdır.

Gereç ve yöntem: Tanta Üniversitesi Pediatri Departmanı Hematoloji/Onkoloji Ünitesinden talassemili çocuklar çalışmaya alındı. Hastaların transfüzyon ve aşılanma hikayeleri, klinik verileri ve an örnekleri alındı. ELISA ile anti-HBs çalışılacağı zamana kadar hastaların serumları $-20^{\circ} \mathrm{C}$ 'de saklandı. Antikor titreleri <10 IU olan hasta serumlarında HBs-Ag arandı.

Bulgular: Hastaların hiç birinin hepatit B virus enfeksiyonu olmamasına karşılık sadece \%20,8'i koruyucu anti-HBs titresine sahipti. Üç yaşından daha büyük olanlarda koruyucu antikor titresi düşme eğilimindeydi ve üç yaşından küçük olan hastalarda anlamlı şekilde daha yüksek koruma yüzdesi vardı $(\% 40,1)(p=0,003)$. Anti-HBs titreleri, yaş, ferritin, karaciğer enzimleri ve transfüzyon süresi veya transfüzyon paket sayısıyla doğru orantılı değildi.

Sonuç: Hastalarımızda koruyucu anti-HBs titreleri üç yaşından sonra düşüş gösterdiler. Bu nedenle talassemili hastaların üç yaşında taranmasını ve ek aşı dozuna ihtiyaç yönünden değerlendirilmesini öneririz.

Anahtar kelimeler: Talassemi, HBV, aşılama, immünojenite 


\section{INTRODUCTION}

Thalassemia syndromes are the most common single gene disorder worldwide; about $3 \%$ of world population carries $ß$ - thalassemia genes. ${ }^{1}$ In Egypt, ß-thalassemia is the most common genetically determined chronic hemolytic anemia with a carrier rate not less than $9 \% .^{2}$ Beta thalassemia major $(\beta-T M)$ is an inherited hemoglobin disorder characterized by failure of production of beta hemoglobin chains; resulting in severe chronic hemolytic anemia requiring regular lifelong blood transfusions and daily iron chelation therapy, or stem cell transplantation to survive. ${ }^{3}$

Frequent blood transfusions for patients with thalassemia have improved not only their survival, but also their quality of life. However, it carries a definite risk of being infected with blood borne viruses. Screening for hepatitis viruses was added to the blood donation battery in Egypt (HBV in 1985 and HCV in 1993). ${ }^{4}$ But, even in countries where the blood supply is screened for viral hepatitis, the risk of parenteral infection is still significant. $^{5}$

The WHO maps Egypt as an intermediate region for HBV infection (HBV prevalence 2\% $-7 \%$ of the population. ${ }^{6,7}$ Studies in Egypt have found HBsAg prevalence to be $4.3 \%{ }^{8}$ Hepatitis $B$ virus (HBV) infection acquired during infancy and early childhood is a major cause of chronic liver disease and liver cancer worldwide. Active immunization by administration of hepatitis $B$ vaccination before exposure to the virus is the most effective way to prevent infection and related hepatocellular carcinoma. ${ }^{9-10}$ However, there is a large argument about the duration of vaccine protection..$^{11-12}$ In Egypt, vaccination against HBV was added to compulsory vaccines in 1992. It is given as three intramuscular injections at ages of 2, 4 and 6 months to all infants. ${ }^{13}$ Three doses of recombinant HBV vaccine had been found to induce a protective response ( $>10 \mathrm{IU} / \mathrm{L}$ anti-HBs) in more than $90 \%$ of healthy adults and children. ${ }^{14}$ Although this vaccine regimen was highly effective and didn't necessitate a booster dose in healthy children, its efficacy was not the same when evaluated in high risk groups. ${ }^{15}$ Saberifiroozi et al. studied health care workers as a high risk group and reported decline in their sustained immunity after 10 years and recommended their revaccination. ${ }^{16}$ Also Saraswat et al. found up to $50 \%$ of repeated transfusion patients to show undetectable levels of the anti-body after vaccination and recommended that they need to be revaccinated. ${ }^{17}$ The argument about the need for revaccination against $\mathrm{HBV}$ in high risk patients encouraged the conduct of this study to evaluate the immunogenic effect of hepatitis $B$ vaccine in thalassemic children at different age groups.

\section{Materials and methods}

One hundred and twenty five patients (74 male and 51 female; with age ranging from 12 months to 16 years) were sequentially enrolled over the period from March 2011 to September 2011. All were thalassemic patients previously diagnosed by complete blood count and hemoglobin electrophoresis, registered at the Hematology/Oncology Unit, Pediatric Department, Tanta University Hospital, and regularly attending the unit for repeated packed cell transfusion. All candidates had received hepatitis $B$ vaccine according to the compulsory schedule of vaccination in Egypt, by three intramuscular injections of $0.5 \mathrm{ml}$ recombinant vaccine at 2,4 and 6 months. Children's medical charts including official child vaccination records were reviewed to ascertain receiving of the primary immunization schedule and to assure that no additional hepatitis $B$ vaccine doses had been received.

All patients were subjected to: History taking with special stress on age at diagnosis, age at start of regular transfusions, inter-transfusion interval, history of splenectomy and complete physical examination. A $5 \mathrm{ml}$ venous blood sample was obtained for performance of the following investigations; complete blood counting, estimation of liver transaminases, serum bilirubin, and serum ferritin levels. A blood sample of $2 \mathrm{ml}$ was centrifuged at 3000 RPM for at least 20 minutes at room temperature then stored at $-20^{\circ} \mathrm{C}$ till tested for hepatitis B s Ag and antibodies titer.

ELISA kits for hepatitis B surface antigen (anti-HBs) in human serum or plasma samples (Produced by G.B. Lippincott Company, USA) were used for quantitative estimation of anti-HBs titer.

Interpretation of results: According to manufacturer instructions, patients with a titer $>10 \mathrm{IU} / \mathrm{L}$ were interpreted as protected, while patients with a titer $<10 \mathrm{IU}$ were considered risky for HBV infection so they were tested for HBs-Ag to detect positive cases which would need confirmation 
with PCR. Hepatitis B surface antigen (HBsAg): done by ELISA technique to detect HBsAg in human serum or plasma samples (Produced by G.B. Lippincott Company, USA).

Interpretation of results: According to manufacture instructions, titer $<0.9$ is negative, $>1$ is positive, and $0.9-1$ is borderline necessitating a confirmatory test.

\section{Statistical Analysis}

Statistical Package for Social Sciences (SPSS, ver.10.0) software was used. Chi square for linear trend was used to compare the levels of antiHBs titer in all age groups, Pearson correlation was used to detect association between anti-HBs and other parameters. For all used tests, $P$ value $<0.05$ was considered statistically significant.

\section{RESULTS}

Among 125 Egyptian thalassemic children investigated, 74 were males (59.2\%) and 51 females $(40.8 \%)$. Their ages at time of data analysis ranged between 12 months and 16 years with a mean age of $7.6 \pm 4.4$ years. Consanguinity was reported in $40 \%$ of patients. Depending on patient's individual response, the average blood transfusions in these children was 4-24 times per year.

Clinically, $96 \%$ of our cases were jaundiced. Hepatomegaly was present in 99 (79.2\%), splenomegaly in $100(80.0 \%)$ and splenectomy had been done in $20(16.0 \%)$. None of our cases had features of liver cell failure or extrahepatic manifestations of HBV infection. The number of children with anti- HBs positive titer $>10$ was 26 (20.8\%) (Tables 1 and 2).

As regards the protective immune response, children aged from 1-3 years showed a higher percent of protection (42.1\%). The level of protection varies with age to reach $13.0 \%$ for age group $3-6,17.4 \%$ for age group $6-9$, and $21.6 \%$ for age group 9-16, with a significant trend for decrease of immune protective titer above the age of 3 years (Table 3 ).

There was no meaningful association between anti-HBs response and age, hemoglobin, ferritin, liver enzymes, duration of transfusion, or total number of transfused packs (Table 4).

Table 1. Clinical and laboratory parameters of studied patients $(n=125)$

\begin{tabular}{lll}
\hline Range & Mean \pm SD & Parameter \\
\hline $1-16$ & $7.55 \pm 4.4$ & $\begin{array}{l}\text { Age (years) } \\
\text { Age at 1st transfusion } \\
\text { (months) }\end{array}$ \\
$15-60$ & $16.2 \pm 13.49$ & $\begin{array}{l}\text { Transfusion interval } \\
\text { (days) }\end{array}$ \\
$4-24$ & $10.73 \pm 4.29$ & $\begin{array}{l}\text { Transfused packs } \\
\text { (200ml) /year }\end{array}$ \\
$5-360$ & $67.19 \pm 64.11$ & $\begin{array}{l}\text { Total no. of transfused } \\
\text { packs }(200 \mathrm{ml})\end{array}$ \\
$550-8000$ & $2671.22 \pm 1620.42$ & Ferritin (ng/ml) \\
$19-107$ & $46.01 \pm 16.729$ & ALT (IU/ml) \\
$18-112$ & $45.11 \pm 17.31$ & AST $(\mathrm{IU} / \mathrm{ml})$ \\
\hline
\end{tabular}

Table 2. Percentage of clinical presentations and laboratory data in the patients $(n=125)$

\begin{tabular}{lll}
\hline Parameter & Frequency & Percentage \\
\hline Consanguinity & 50 & $40 \%$ \\
Jaundice & 120 & $96 \%$ \\
Hepatomegaly & 99 & $79.2 \%$ \\
Splenomegaly & 100 & $80 \%$ \\
Splenectomy & 20 & $16 \%$ \\
Anti-HBs protective titer & 26 & $20.8 \%$ \\
\hline
\end{tabular}

Table 3. Immune response of thalassemic patients with hepatitis $B$ vaccination $(n=125)$

\begin{tabular}{lccc}
\hline Age groups & Total & $\begin{array}{c}\text { Non protected } \\
\text { (Anti-HBs <10IU/L) }\end{array}$ & $\begin{array}{c}\text { Protected } \\
\text { (Anti-HBs >10 IU/L) }\end{array}$ \\
& No.(\%) & No. (\%) & No. (\%) \\
\hline 1-3 years(GI) & $19(15.2)$ & $11(57.9)$ & $8(42.1)$ \\
3-6 years(GII) & $46(36.8)$ & $40(86.96)$ & $6(13.04)$ \\
6-9 years(GIII) & $23(18.4)$ & $19(82.61)$ & $4(17.39)$ \\
9-16 years(GIV) & $37(29.6)$ & $29(78.37)$ & $8(21.63)$ \\
Total & $125(100)$ & $99(79.2)$ & $26(20.8)$ \\
\hline
\end{tabular}

$\chi^{2}=8.700, p=0.003^{*}$ 
Table 4. Correlation of anti-HBs titer to patients' parameters $(n=125)$

\begin{tabular}{lll}
\hline Anti-HBs titer & $\mathrm{p}$ & $\mathrm{r}$ \\
\hline Age & 0.479 & -0.0639 \\
Hemoglobin & 0.709 & 0.0337 \\
Ferritin & 0.205 & -0.114 \\
ALT & 0.149 & 0.13 \\
AST & 0.420 & 0.07 \\
Duration of transfusion & 0.754 & 0.0283 \\
Number of packs & 0.575 & 0.0506 \\
\hline
\end{tabular}

\section{DISCUSSION}

The universal HBV vaccination in infancy has significantly reduced the burden of the disease in high-prevalence populations. ${ }^{18}$ Three doses of recombinant $\mathrm{HBV}$ vaccine induce a protective response (>10 IU/L anti-HBs) in more than $90 \%$ of healthy adults and children. ${ }^{14}$ The annual decay rate of hepatitis $B$ surface antibody (Anti-HBs) has been estimated to be $10.2 \%$ in healthy children who did not receive a booster dose. ${ }^{18}$

Multiple studies regarding immunity level and duration of acquired immunity from hepatitis $B$ vaccination have been performed in high risk groups with controversial results. Seroconversion reached $80 \%$ after 6 years of vaccination in vaccinated thalassemic children in one study, 19 and $85 \%$ in high risk infants in another study. ${ }^{20}$ But, haemodialysis patients have low persistence of the protective titer with only $38 \%$ seroprotected 10 years after vaccination. ${ }^{21}$ In a study by Azarkeivan in 2009 a booster dose of vaccine increased the protection level among thalassemia patients from $46.9 \%$ to $69.4 \% 22$. Thus, the matter of boosting remains questionable, especially in high risk groups.

In this study, from 125 vaccinated Egyptian thalassemic children between 1-16 years of age, only $26(20.8 \%)$ had a protective anti HBs levels (titer $>10 \mathrm{IU} / \mathrm{L}), 52(41.6 \%)$ had a titer $<1 \mathrm{IU} / \mathrm{L}$, and $47(37.6 \%)$ had titer between 1-10 IU/L. Our results were consistent with an Iranian study done in Kerman on 215 children with major thalassemia, where $34.8 \%$ were non responders and the remaining were either low or good responders. ${ }^{23}$ Sharifi et al. 2010 in another study reported $89.9 \%$ anti-HBs positivity in thalassemic chil- dren. ${ }^{24}$ However, their results were qualitative. So it doesn't reflect the actual percentile for patients with anti-HBs protective titer.

In an Egyptian study, 48 children subjected to repeated blood transfusion due to different diseases (Thalassemia, sickle cell anemia and leukemia) were tested. Their response to HBV vaccine was significantly lower than response reported for age and sex matched healthy controls. The same study reported $39.6 \%$ of those children to have a less than protective titer of Anti-HBs. ${ }^{25}$

In the present study, the highest percentage of immune protected patients $(42.1 \%)$ was reported in children below 3 years of age. There was a sharp decline in percentage of protected children among patients aged between 3-6 years $(13.0 \%)$, but this decline was attenuated with the advancement of age to $21.6 \%$ having a protective titer in age group 9-16 years. This sharp decline was previously reported even in healthy children as protective serum Anti-HBs titer was reported in $75 \%$ of children within 2 years of vaccination and decreased to $48.2 \% 7$ years post vaccination in Chinese children ${ }^{26}$. In Alaskan children receiving recombinant HBV vaccine (same used in Egypt), Anti-HBs titer $>10$ IU was detected in $29 \%$ of children versus $14 \%$ of adolescents before booster dose administration. ${ }^{27}$

An Egyptian study performed in Ismailia governorate found the percent of good responders (Anti-HBs titer $>100 \mathrm{IU}$ ) to decline from $75.3 \%$ one month after vaccination to $28 \%$ after one year follow up of the same patients. The protective titer (>10 IU) in that study was reported in $93.7 \%$ after one month versus $82 \%$ after one year follow up. ${ }^{28}$ This antibody titer decline can explain the significant difference in antibody titer reported in our study between children less than 3 years of age and other age groups.

The limitation of our results is lack of records for the patient's initial response just after vaccination. So we could not avouch the exact cause of lacking protective level after the age of 3 years. This low titer may be due to decline of previously formed anti bodies or initial post vaccination poor response.

Most of our patients lacked protective antiHBs titers. However, none of our patients was HBsAg positive. Our results were in accordance with results reported by Sharifi et al. 2010 who reported $1.0 \%$ of thalassemic Iranian patients to be 
HBsAg positive but PCR negative for HBV DNA despite more than $10 \%$ of their patients having negative Anti-HBs. ${ }^{24}$ Also, Samandari et al., who reported no case of HBV infection among 166 Alaskan vaccinated children and 138 vaccinated adolescents despite the presence of a non-protective Anti-HBs titer in $71 \%$, and $86 \%$ of them respectively. ${ }^{27}$ Our results are in accordance with those of Ocak et al. who reported only 3 out of 399 Turkish thalassemic patients to be HBsAg positive $(0.75 \%) .{ }^{29}$

In Egypt, there has been a decline in the incidence of HBV infection in multiple-transfused patients in recent years due to some precautions taken, such as improvement of blood screening procedures, use of disposable equipment for invasive procedures and initiation of free routine immunization for all infants. Relevant studies conducted in the Hematology Clinic, New Children's Hospital, Cairo University Egypt, on thalassemic patients detected HBsAg positivity in $16.5 \%$ in 1993 , but only one out of 50 thalassemic patients (2\%) was HBsAg positive in year 2009. ${ }^{30}$ However, our results were different from those of Mokhles et al. who reported $31.3 \%$ positivity for HBs-Ag in repeatedly transfused patients..$^{25}$ This variation may be related to heterogeneity of their patients as some of them had hematological malignancies, and it is not mentioned if those patients were or were not immune suppressed due to chemotherapy at time of study.

Except for this variant, our results were consistent with Mokhles et al., who concluded that high risk groups of children with repeated blood transfusion proved to become significantly risky for HBV infection secondary to loss of Anti-HBs protective titer after a variable period of time. And we can add that this significant drop occurs above the age of three years. ${ }^{25}$

From this study, we can conclude that: HBV infection is not common among vaccinated thalassemic patients in Egypt, even in those with titers below $10 \mathrm{IU} / \mathrm{L}$. Both the percentage of protected children and protective titer levels are reduced in patients above 3 years of age. So we recommend screening of thalassemic patients for Anti-HBs titer at age of 3 years to evaluate the need of a booster dose.

\section{Funding}

This work was supported by Tanta University postgraduate and research section, competitive project funding [fund number TU-O4-14-2009].

\section{Conflicts of interest: None declared.}

Ethical approval: Approved by Tanta University Ethical Committee.

\section{REFERENCES}

1. Sexana A, Phadke SR. Feasibility of thalassemia control by extended family screening in Indian context. J Health Popul Nutr 2002; 20:31-35.

2. El-Beshlawy A, Kaddah N, Moustafa A, et al. Screening for ß-thalassemia carriers in Egypt: Significance of the osmotic fragility test. East Mediterr Health J 2007; 13:224-230.

3. Rund D, Rachmilewitz E. ß-Thalassemia. N Engl J Med 2005; 353:1135-1146.

4. Bassily S, Hyams K, Fouad R, Samfaan M, and Hibbs R. A high risk of hepatitis $C$ infection among Egyptian blood donors: The role of parenteral drug abuse. Am J Trop Med Hyg 52; 1995: 503-505.

5. Hauri A, Armstrong G, Hutin Y. The global burden of disease attributable to contaminated injections given in health care settings. Int J STD AIDS 2004; 15: 7-16.

6. Davis AR, Rosenthal P. Hepatitis B in children. Pediatr Rev 2008; 29:111-120

7. Elisofon SA, Jonas MM. Hepatitis B and C in children: current treatment and future strategies. Clin Liver Dis 2006; 10:133148.

8. El-Gilany AH, El-Fedawy S. Bloodborne infections among student voluntary blood donors in Mansoura University, Egypt. East Mediterr Health J 2006; 12:742-748.

9. Kao JH; Chen DS. Global control of hepatitis B virus infection, Lancet Infect Dis 2002; 2:395-403.

10. Kirk GD. Hepatitis B vaccination and liver cancer. In: Stewart BW, Kleihues P (Eds).World Cancer Report. Lyon: IARC Press, 2003, 144-147.

11. Bonanni P, Pesavento $G$, Bechini A, et al. Impact of universal vaccination programs on the epidemiology of hepatitis $B: 10$ years of experience in Italy. Vaccine 2003; 21: 685-691.

12. Fitzsimons $D$, François $G$, Hall $A$, et al. Long-term efficacy of hepatitis $B$ vaccine, booster policy, and impact of hepatitis $B$ mutants. Vaccine 2005; 23:4158-4166.

13. World Health Organization. Last update: 3 October 2011, Immunization Profile-Egypt, WHO Vaccine Preventable Diseases Monitoring System web site, http://apps.who.int/immunization_monitoring/en/globalsummary/countryprofileresult.cfm?C=egy [accessed Oct 5, 2011]

14. Rivkina A, Pharm D, Rybalov S. Chronic hepatitis B: Current and future treatment options. Pharmacotherapy 2002; 22: 721-737.

15. But DY, Lai CL, Lim WL, Fung J, Wong DK, Yuen MF. Twenty-two years follow-up of a prospective randomized trial of hepatitis $B$ vaccines without booster dose in children: Final report. Vaccine 2008; 2; 26:6587-6591.

16. Saberifiroozi M, Gholamzadeh S, Serati AR. The long-term immunity among health care workers vaccinated against hepatitis B virus in a large referral hospital in southern Iran. Arch Iran Med.2006; 9:204-207. 
17. Saraswat S, Banerjee K, Chaudhury N, et al. Post transfusion hepatitis type $\mathrm{B}$ following multiple transfusions of $\mathrm{HBsAg}$ negative blood. J Hepatol 1996; 25:639-643.

18. Chang $\mathrm{MH}$. Impact of hepatitis $B$ vaccination on hepatitis $B$ disease and nucleic acid testing in high-prevalence populations. J Clin Virol 2006; 36: 45-50.

19. Dentico P, Buongiorno A, Volpe A, Zavoianni D, De Mattia $D$, Sabato V. Long term persistence of anti-HBs after hepatitis B immunization in thalassemic patients. Infection 1992; 20:276-278.

20. Wu JS, Hwang LY, Goodman KJ, Beasley RP. Hepatitis B vaccination in high-risk infants: 10 year follow-up. J Infect Dis. 1999; 179:1319-1325.

21. Peces R, Laures AS. Persistence of immunologic memory in long-term hemodialysis and healthcare workers given hepatitis $B$ vaccine: Role of a booster dose on antibody response. Nephron 2001; 89: 172-176.

22. Azarkeivan A, Karimi G, Shaiegan M, Maghsudlu M, Tabbaroki A. Antibody titration and immune response of Iranian beta-thalassemic patients to hepatitis $B$ virus vaccine (booster effect). Pediatr Hematol Oncol 2009;26:195-201.

23. Vahidi AA, VaresVazirian M, Shamsadini A, et al. Determination of hepatitis B surface antibody titer in vaccinated children with major thalassemia in Kerman, Iran. Iran J Immunol 2006; 3:30-34.
24. Sharifi Z, Milani S, Shooshtari M. Study on efficacy of hepatitis $B$ immunization in vaccinated beta thalassemia children in Tehran. Iran J Pediatric 2010; 20: 211-215.

25. Mokhles M, El Ashry R, Sedky M , et al. Long Term Efficacy of Hepatitis B Vaccine among High Risk Multiple Blood Transfusion Children in Egypt J Appl Sci Res. 2009; 5:2504-2510

26. Li H, Li RC, Liao SS, Yang JY, Zeng XJ, Wang SS. Persistence of hepatitis $B$ vaccine immune protection and response to hepatitis B booster immunization. World J Gastroenterol 1998;4: 493-496.

27. Samandari T, Fiore A, Negus S, et al. Differences in response to a hepatitis $B$ vaccine booster dose among Alaskan children and adolescents vaccinated during infancy. Pediatrics 2007; 120: e373-e381

28. El Ghandour S, El Sayed H, Abdel Hamid A, Gad S. Effectiveness of Hepatitis B Vaccination in Egyptian infants in Ismailia Governorate. Suez Canal University Med J 1998; 1:123-130.

29. Ocak S, Kaya H, Cetin M, Gali E, Ozturk M. Seroprevalence of hepatitis $B$ and hepatitis $C$ in patients with thalassemia and sickle cell anemia in a long-term follow-up. Arch Med Res 2006; 37:895-898

30. El Gawhary S, Omar N, Abdel Rahman L, Mahmoud M. Hepatic viruses screening in multitransfused Egyptian thalassemia patients. J Arab Child 2009;20:193-202. 